\title{
Material Evolution of Heat-Treated Aluminum Alloy 6101 Quenched in Different Media
}

\author{
O. M. Ikumapayi ${ }^{1 *}, E . T$. Akinlabi $^{2,3}, G . O$. Agwu $^{1}, S$. Akande $^{1}, I . D . \mathrm{Uchegbu}^{1}, S . O . \mathrm{Fatoba}^{3}, S . A . \mathrm{Akinlabi}^{4}$ \\ ${ }^{1}$ Department of Mechanical and Mechatronics Engineering, Afe Babalola University, Ado Ekiti, 360101, Nigeria \\ ${ }^{2}$ Pan African University of Life and Earth Sciences (including Health and Agriculture), Ibadan, Nigeria. \\ ${ }^{3}$ Department of Mechanical Engineering Science, University of Johannesburg, 2006, South Africa \\ ${ }^{4}$ Department of Mechanical Engineering, Butterworth Campus, Walter Sisulu University, South Africa
}

\begin{abstract}
The goal of this study was to investigate the changing characteristics of Heat-Treated Aluminum Alloy 6101 quenched in various media. The research methodology of this research includes performing heat treatment on the Aluminum Alloy 6101 samples at various temperatures, specifically $250^{\circ} \mathrm{C}, 350^{\circ} \mathrm{C}$ and $450^{\circ} \mathrm{C}$ as well as carrying out quenching processes of the samples using Brine and Water as the main quenchants, and then allowing some samples to cool in the furnace and the rest to be normalized in air, after which mechanical tests (hardness and impact test) will then be carried out on the samples, followed by the microstructural analysis of the alloy. The study concluded that Aluminum Alloy 6101 should be heated to $250^{\circ} \mathrm{C}$ to achieve the greatest positive effect on its hardness properties, and the air was found to be the best cooling medium. It was also established that Brine Solution used as a quenching media has no significant effect on the hardness property of Aluminum Alloy 6101. Furthermore, the findings revealed that $350^{\circ} \mathrm{C}$ is the best temperature for increasing the Impact Absorbed Energy (IE) and Impact Strength (IS) of Aluminum Alloy 6101, and that cooling in the furnace also increases the IE and IS.
\end{abstract}

\section{Introduction}

Aluminum, a silvery-white metal is the $13^{\text {th }}$ element in the periodic table. It is the most common metal on the surface of the Earth, and it accounts for $8 \%$ of the central mass of Earth. Aluminum is also the $3^{\text {rd }}$ most common chemical element on Earth, after oxygen and silicon. Aluminum was produced for the first time in 1824 and after about 50 years, people were able to learn to manufacture it on an industrial scale [1]. An aluminum alloy constitutes a mixture of metallic and metalloid elements, for example, silicon, tin, manganese, copper, and magnesium can combine with pure aluminum to improve its properties, most notably its strength. Aluminum can gain a lot of strength with the right combination of elements. Aluminum alloys also offer the same advantage as pure aluminum, and since their melting point is low they are also relatively costeffective [2].

The alloys of aluminum are classified into many categories;Depending on their material properties, such as; its tendency to react to thermal and mechanical treatment. Also, the major alloying factor used.

Two identification systems for aluminum are the wrought designation and the cast designation systems. The wrought method is a four-digit system. The very first digit $(\mathbf{X x x x})$ denotes the main alloying factor that has been applied to the aluminum alloy and is also used to identify the aluminum alloy series (1000-8000 series).
The second digit $(\mathrm{x} \mathbf{X} \times \mathbf{x})$ denotes a change of the specific alloy if it differs from " 0 ", and the third and fourth digits $(\mathrm{xx} \mathbf{X X})$ are arbitrary numbers provided to classify a specific alloy in the sequence if they differ from " 0 ". For example, in alloy 6101, the number " 6 " denotes that it is magnesium and silicon alloy, the "1" denotes that it is the $1^{\text {st }}$ modification to the original alloy 6101 , and the " 01 " denotes that it belongs to the $6 \mathrm{xxx}$ series [3].

Aluminium alloy 6101 is one of the most common alloys among the 6xxx aluminium (Al) alloy series with Magnesium and Silicon as its primary alloying elements. They are a technologically important class of alloys as they are versatile, heat treatable, have moderate strength, have outstanding weldability, and also good corrosion resistance [4]. In AA6101, magnesium and silicon are the main alloying agents. It has been confirmed that magnesium is one of the most powerful and widely used aluminum alloying elements.

Alloys have moderate strength properties but offer very good corrosion resistance and formability in the series. Due to these properties, AA6101 is now commonly made use of in the manufacturing process of windows and door parts, architectural applications, the development of fuses, electrical conductors, and screw machine parts. This study will relate to newly developed technologies in which AA6101 can be used and how to alter the alloy to boost engineering progress.

\footnotetext{
* Corresponding author: author@e,e-mail.org
} 
with a comma after all except the last author, which is separated by comma + "and". Do not use academic titles.

Affiliations of authors should be typed in 9-point Times. They should be preceded by a numerical superscript corresponding to the same superscript after the name of the author concerned. Please ensure that affiliations are as full and complete as possible and include the country.

Magnesium and Silicon are the primary alloying factors for 6XXX series aluminum. Together these alloying elements form Magnesium Silicide within the alloy, making this series heat treatable, weldable, and highly formable with moderately high strength and good corrosion resistance. Alloy 6101 is the most common alloy in this series. It is a heat treatable alloy with moderate strength and maximum electrical conductivity, ideally suited for conductive materials used in the design and manufacture of electrical power distribution components and equipment. It is commonly used in the fabrication of trucks and marine frames [5].

\subsection{Purpose of Heat Treatment}

Many materials may have to go through procedures that change their grain structure during the manufacturing process. Heat treatment is a technique of changing the physical properties of metals, such as their ductility, and then improving them to meet different industry demands by utilizing controlled heating and cooling procedures. These heat treatments differ based on the metal form and the mechanical properties needed for the parts' operation. To ensure that the metal meets the required strength specifications, the proper heat treatment procedures must be followed [6]. The hardness and strength of some aluminum alloys (e.g. the $2 \mathrm{xxx}$, $6 \mathrm{xxx}, 7 \mathrm{xxx}$, and $8 \mathrm{xxx}$ series) can be increased through heat treatment. Natural aging, artificial aging, annealing, solution heat treatment, homogenizing are some of the aluminum heat treatments. Furnace temperatures can range from 240 to $1000^{\circ} \mathrm{F}$, depending on the operation [7].

\subsection{Heat Treatment of Aluminium Alloy}

The hardness and strength of some aluminum alloys (e.g. the $2 \mathrm{xxx}, 6 \mathrm{xxx}, 7 \mathrm{xxx}$, and $8 \mathrm{xxx}$ series) can be increased through heat treatment. Natural aging, artificial aging, annealing, solution heat treatment, homogenizing is some of the aluminum heat treatments. Furnace temperatures can range from 240 to $1000^{\circ} \mathrm{F}$, depending on the operation [8].

Annealing aims to reconfigure the crystalline grain structure, restore slip planes, and allow the part to be shaped without using excessive force. For a workhardened aluminum alloy to be annealed, it must be heated to a temperature ranging from 570 to $770^{\circ} \mathrm{F}$ for a certain period, which can range from thirty minutes to three hours. The annealing time and temperature are determined by two factors: the size of the component being annealed and the alloy composition. Additionally, non-heat-treatable aluminum alloys can be successfully annealed [8]. Homogenizing is a technique for uniformly distributing precipitating elements within an aluminum component. When working on cast aluminum alloy components, this is usually needed. Increasing the temperature of an aluminum element to just below its melting point, which is typically between $900^{\circ} \mathrm{F}$ and $1000^{\circ} \mathrm{F}$, homogenizes it. After the entire component has reached this homogenizing temperature, it is allowed to cool slowly. The result is a cast part with a uniform internal structure.

During the solution heat treatment process, the elements that cause age hardening are dissolved. The dissolved elements then solidify into spheroids, forming a homogenous structure. The temperature used varies depending on the aluminum alloy composition. However, the temperature usually falls between $825^{\circ} \mathrm{F}$ and $980^{\circ} \mathrm{F}$ but it must be within $10^{\circ} \mathrm{Fof}$ the target temperature. If the temperature is not reached the solution heat treatment will be ineffective. If the temperature is too low, the part may lose strength, the part may be discolored and crucial elements may melt if the temperature is too high, or the part may experience increased strain [9]. Over time, elements that are dissolved in the aluminum will continue to precipitate out after it has been solution heat-treated. This allows the grains to lock in place, increasing the aluminum's natural strength. This process is known as aging. In the same vein, some aluminum alloys need the dissolved elements to be completely precipitated out to achieve optimum hardness. During natural aging at room temperature, not all aluminum alloys achieve adequate hardness. Some alloys can only harden to a certain degree, but this can be overcome by artificial hardening [10-11].

\section{Materials and Methods}

Aluminum Alloy 6101 (AA6101), a member of the $6 \mathrm{XXX}$ series is the primary metal substrate used in this project. The chemical composition in weight percentage (Wt. \%) and other technical information about the sample purchased are shown in Table 1[12].

Table 1. Technical Details of Aluminum Alloy 6101 Sample (AZO, 2012)

\begin{tabular}{|c|c|c|}
\hline S/N & Quality & Quantity \\
\hline 1. & Pure Aluminum (wt. \%) & 98.9 \\
\hline 2. & Magnesium (wt. \%) & 0.6 \\
\hline 3. & Silicon (wt. \%) & 0.5 \\
\hline 4. & Tensile Strength (MPa) & 97 \\
\hline 5. & Yield Strength (MPa) & 76 \\
\hline 6. & Density (kg/m $\left.\mathrm{m}^{3}\right)$ & $2.7 \times 10^{3}$ \\
\hline
\end{tabular}




\begin{tabular}{|c|c|c|}
\hline 7. & Poisson's Ratio & 0.33 \\
\hline 8. & Dimension (mm) & $120 \times 30$ \\
\hline 9. & Thickness $(\mathrm{mm})$ & 6 \\
\hline
\end{tabular}

\subsection{Sample Preparations}

The purchased bars were cut into short pieces of equal length. Twenty-Seven pieces of $120 \mathrm{~mm} \times 30 \mathrm{~mm}$ samples were cut out of the AA6101 bars. Three untreated samples were separated as received (control) samples while twenty-four samples were selected for heat treatment. Two samples each were labelled to be heat treated at three different temperatures $250^{\circ} \mathrm{C}, 350^{\circ} \mathrm{C}$ and $450^{\circ} \mathrm{C}$ in the muffle furnace and quenched afterward in different media as shown in Table 2.

Table 2. Samples Selected for Heat Treatment at $250^{\circ} \mathrm{C}$, $350^{\circ} \mathrm{Cand} 450^{\circ} \mathrm{C}$

\begin{tabular}{|c|c|c|c|c|c|c|}
\hline $\begin{array}{l}\mathbf{S} / \\
\mathbf{N}\end{array}$ & $\begin{array}{c}\text { Quenchi } \\
\text { ng } \\
\text { Medium }\end{array}$ & $\begin{array}{l}\text { Sampl } \\
\text { es at } \\
250^{\circ} \mathrm{C}\end{array}$ & $\begin{array}{c}\text { Sampl } \\
\text { es at } \\
350^{\circ} \mathrm{C}\end{array}$ & $\begin{array}{c}\text { Sampl } \\
\text { es at } \\
450^{\circ} \mathrm{C}\end{array}$ & $\begin{array}{l}\text { No. of } \\
\text { sampl } \\
\text { es }\end{array}$ & $\begin{array}{c}\text { Lab } \\
\text { el }\end{array}$ \\
\hline 1. & Water & 2 & 2 & 2 & - & W \\
\hline 2. & Brine & 2 & 2 & 2 & - & B \\
\hline 3. & $\begin{array}{l}\text { Air- } \\
\text { cooled }\end{array}$ & 2 & 2 & 2 & - & A \\
\hline 4. & $\begin{array}{c}\text { Furnace- } \\
\text { cooled }\end{array}$ & 2 & 2 & 2 & - & $\mathrm{F}$ \\
\hline 5. & $\begin{array}{c}\text { As } \\
\text { received } \\
\text { (Control } \\
\text { Sample) }\end{array}$ & - & - & - & 4 & $\mathrm{C}$ \\
\hline \multicolumn{7}{|c|}{ Total number of samples $(8 \times 4)=28$} \\
\hline
\end{tabular}

\subsection{Heat Treatment Process}

The heat treatment process was carried out at a rate greater than the critical cooling rate, (i.e. at a rate greater than the minimum rate of cooling to ensure that the elements stay in solid condition) [13-14]. An electric muffle furnace with a maximum temperature capacity of $800^{\circ} \mathrm{C}$. The samples were quenched in different media, specifically; water (4 Liters) and brine solution of 0.15 Molar concentrations (4 Liters), and some of them were allowed to cool in the air and the others in the furnace.

Eight samples were put into the furnace and heattreated to a temperature of $250^{\circ} \mathrm{C}$. The samples were soaked at $250^{\circ} \mathrm{C}$ for sixty-five (65) minutes and then the furnace was switched off. Two samples each were quenched in water and brine solution while another two were brought out of the furnace and left in the air to cool down (air-cooled). The remaining two were left in the furnace to gradually lose heat at the furnace cooling rate until the normal room temperature was attained (furnacecooled). The procedure was repeated at $350^{\circ} \mathrm{C}$ and $450^{\circ} \mathrm{C}$ using the same cooling media and quenching process and eight samples at each temperature. Figure 1. shows a cross-section of the AA6101 samples after heat treatment.

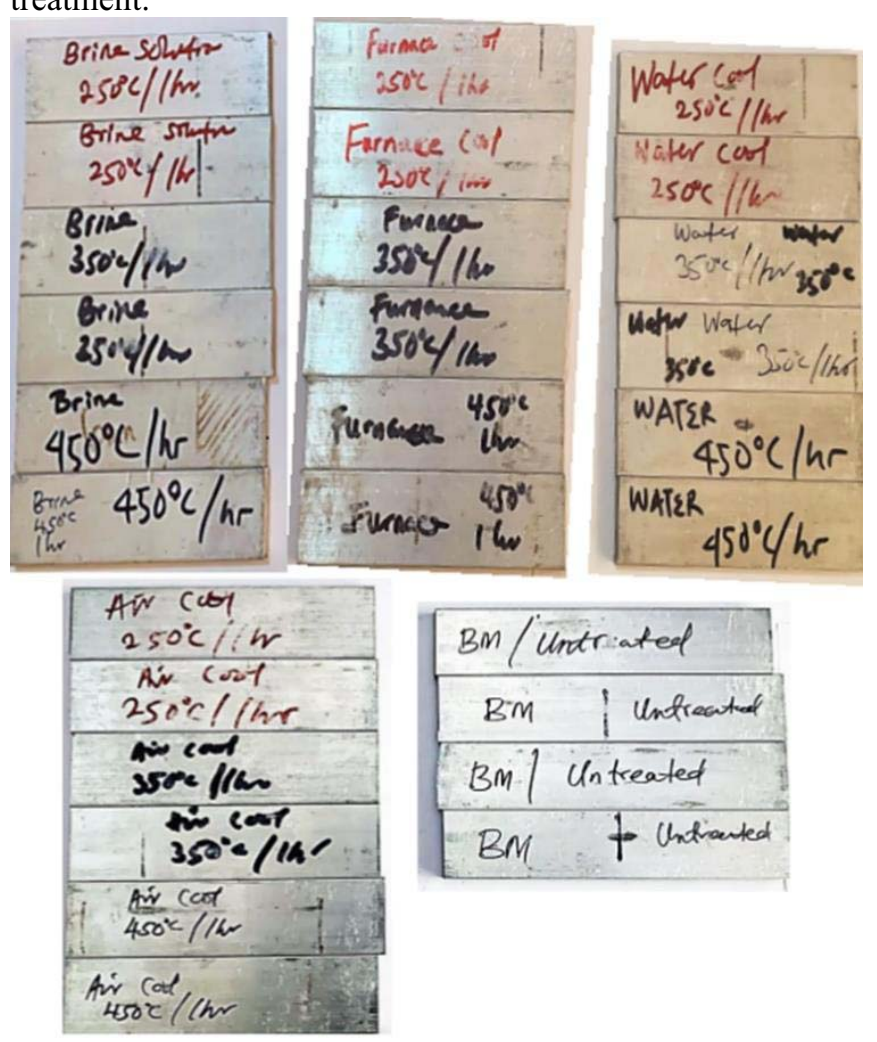

Fig 1. Heat Treated and untreated Samples of AA6101

\subsection{Mechanical Characterization Methods}

ATICO Brinell Hardness Tester was used to conduct a microhardness test on all the samples. The diameter (D) of the selected indenter was $1.6 \mathrm{~mm}$ and the load selected was set to $100 \mathrm{Kgf}$. The sample was cleaned and made free of dirt and grease. The load was applied on the specimen using the Load/Unload lever, the scale deflector was allowed to rest for 15 seconds before taking the reading. The experiment was repeated two times and $\mathrm{d} 1, \mathrm{~d} 2$, and $\mathrm{d} 3$ were recorded. The average diameter was calculated (i.e.i.e. $\frac{d 1+d 2+d 3}{3}$ ). The diameter (d) of the indentation was measured using a microscope and micrometer. Appendix A shows the student carrying out the hardness test. The Brinell Hardness Number $(\mathrm{BHN})$ for $\mathrm{d} 1, \mathrm{~d} 2$, and $\mathrm{d} 3$ were calculated as $\mathrm{BN} 1, \mathrm{BN} 2$, and $\mathrm{BN} 3$ respectively using equation 1 while the Brinell's Hardness Number (BHN) for each specimen was calculated using equation 2 .

$$
B N=\frac{P}{\pi D / 2(D-(\sqrt{D 2}-d 2))}
$$




$$
B H N=\frac{B N 1+B N 2+B N 3}{3}
$$

Where $\mathrm{P}=\operatorname{Load}(\mathrm{Kgf})$

$\mathrm{D}=$ diameter of the indenter $(\mathrm{mm})$

$\mathrm{d}=$ diameter of indentation $(\mathrm{mm})$

In the same vein, ATICO Charpy Impact Tester was used to carry out Impact loading. The samples were cut into standard Charpy test specimens of $55 \mathrm{~mm}$ length and $10 \mathrm{~mm}$ breadth. A $45^{\circ}$ notch of $2 \mathrm{~mm}$ depth and $0.25 \mathrm{~mm}$ root radius was cut at the center of each specimen as shown in Figure 2.

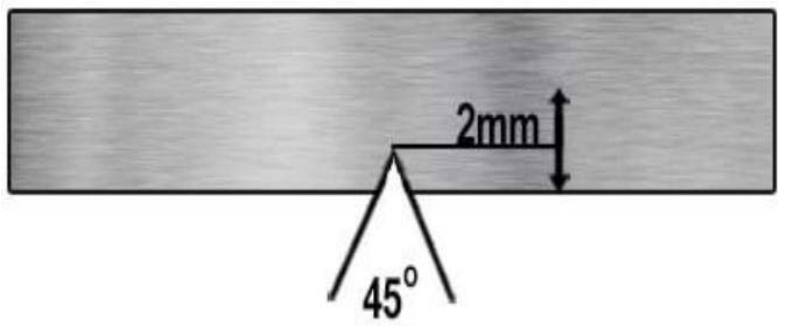

Fig.2. Standard V-Notch Charpy Test Sample

One of the three specimens labeled W25O (water quenched at $250^{\circ} \mathrm{C}$ ) was selected and cleaned. The pendulum was moved up to its locked position and ensured that it was locked at a $160^{\circ}$ pre-swing angle. The path of swing for the pendulum was cleared and all safety guards were put in place. The specimen was placed in the impact testing machine's vice in such a way that the notch was at the center and backing the hammer. The scale pointer was set to the default position and safety considerations were reviewed. The pendulum was released using the release mechanism to strike the specimen at the center and record the impact energy absorbed 'WE1' (in joules) directly from the scale. The experiment was repeated for the second W250 specimen, and WE2 was recorded. The average Impact Absorbed Energy WIE250 (in Joules) and Impact Strength 'IS' (in Joules $/ \mathrm{m}^{2}$ ) for Water quenched specimen at $250^{\circ} \mathrm{C}$ was calculated using equations 2 and 3 and the procedures were repeated for other samples.

$$
\begin{aligned}
& W E 250=\frac{W E 1+W E 2+W E 3}{3} \\
& I S=\frac{W E 250}{A}
\end{aligned}
$$

\subsection{Microstructural Evolution Characterization}

Samples were taken for microstructural analysis to investigate and compare the effect of heat treatment and quenching media on the microstructure properties of the samples.Optical microscopy was conducted using Olympus BX51M and Olympus SZX16 optical microscopes. The Olympus BX51M was used to observe the microstructure of the samples. Digital output was captured and processed using Olympus Stream Essential software. The optical microscope was used to study the microstructural evolution of the samples of AA6101. Images of the microstructural features for different quenching media were taken at a specified magnification on the optical microscope. The microstructural examinations were performed to reveal the efficacy of bonding of quenching media in the heat-treated aluminum alloy.

\subsubsection{Preparation of samples for microstructural analysis}

Before microstructural analysis, preparations of samples (grinding, polishing, and etching) were carried out.

i. Grinding: Samples of heat-treated AA6101 were ground using silica carbide paper of different sizes on the grinding machine to obtain a smooth surface for microstructural analysis. The detailed procedures used for the grinding process are presented in Table 3.

Table 3 Metallographic Procedure Employed in Grinding

\begin{tabular}{|c|c|c|c|c|}
\hline Step & $\begin{array}{c}\text { plane } \\
\text { grinding }\end{array}$ & $\begin{array}{c}\text { final } \\
\text { grinding } \\
\mathbf{1}\end{array}$ & $\begin{array}{c}\text { final } \\
\text { grindin } \\
\mathbf{g} \mathbf{2}\end{array}$ & $\begin{array}{c}\text { final } \\
\text { grindin } \\
\mathbf{g} \mathbf{3}\end{array}$ \\
\hline $\begin{array}{c}\text { Abrasive/ } \\
\text { Surface }\end{array}$ & SiC Paper & SiC Paper & $\begin{array}{c}\mathrm{SiC} \\
\text { Paper }\end{array}$ & $\begin{array}{c}\mathrm{SiC} \\
\text { Paper }\end{array}$ \\
\hline $\begin{array}{c}\text { Grit/Susp } \\
\text { ension }\end{array}$ & 320 & 800 & 1200 & 4000 \\
\hline $\begin{array}{c}\text { Lubricant } \\
\text { RPM }\end{array}$ & 300 & 300 & 300 & 300 \\
\hline Force (N) & 150 & 150 & 150 & 150 \\
\hline $\begin{array}{c}\text { Time } \\
\text { (Sec) }\end{array}$ & $\begin{array}{c}\text { Until } \\
\text { Plane }\end{array}$ & 30 & 30 & 30 \\
\hline
\end{tabular}

ii. Polishing: Polishing was done on the entire sample to a mirror finish surface. The essence is to remove contaminants, impurities, and scratches from the surface of the heat-treated materials before etching them. The process used for the polishing process is presented in Table 4.

Table 4. Metallographic Procedure Employed in Polishing

\begin{tabular}{|c|c|c|}
\hline STEP & $\begin{array}{c}\text { INITIAL } \\
\text { POLISHING }\end{array}$ & FINAL POLISHING \\
\hline Surface & MD-Mol & OP-Chem \\
\hline Suspension & DiaPro Mol & OP-s \\
\hline RPM & 150 & 150 \\
\hline Force (N) & 150 & 0 \\
\hline Time (Min) & 4 & 2.5 \\
\hline
\end{tabular}


iii. Etching: To reveal the microstructural features after grinding and polishing, etching was done on the samples. The etchant used is Weck's reagent. The samples were pre-etched for 1 minute using 2 grams of Sodium Hydroxide $(\mathrm{NaOH})$ and $100 \mathrm{ml}$ distilled water and immediately deepened in less than 15 seconds in 4 grams of Potassium Permanganate $\left(\mathrm{KMnOH}_{4}\right), 1$ gram of $\mathrm{NaOH}$, and $100 \mathrm{ml}$ of distilled water. The etchant attacked the grain boundaries and gave a clear image of the size of the grains. The etched samples were analyzed under the microscope.

\section{Results and Discussions}

The results obtained from the various tests analysis conducted on the heat-treated AA6101 specimens are presented in this chapter for further analysis, discussions, and comparisons.

\subsection{Hardness Test Results}

The result of the Brinell Hardness Test of the heattreated samples of AA6101 quenched in Water (W), Brine (B), cooled in Air (A), and cooled in the Furnace (F) are shown in Table 4.1. The Brinell Hardness Number for each specimen was derived using equation (2):

$B H N=\frac{B N 1+B N 2+B N 3}{3}$

Table 5 and Figure 3 show the comparison of the hardness properties of heat-treated AA6101 specimens quenched in Water and Brine, cooled in Air and Furnace with that of the Control metal. It was observed that the various temperatures $250^{\circ} \mathrm{C}, 350^{\circ} \mathrm{C}$, and $450^{\circ} \mathrm{C}$ selected for the heat treatment of AA6101, have a significant influence on the hardness property of the specimens. The experiment revealed that the $\mathrm{BHN}$ increases only at $250^{\circ} \mathrm{C}$, irrespective of the quenching medium as compared to the base metal (Control). Also, a reduction was observed in the $\mathrm{BHN}$ at $350^{\circ} \mathrm{C}$ and $450^{\circ} \mathrm{C}$ in quenching and cooling media (W, B, and F). From the graph, it was observed that out of the four quenching and cooling media, Air (A) had the greatest positive effect on the hardness property of AA6101, as cooling it in the air increased the BHN by $50 \%$. Also, allowing the specimens to cool down in the Furnace (F) increased the $\mathrm{BHN}$ by $25 \%$ and when the specimens are quenched in water (W), the BHN increased by a mere $10 \%$. The graph has also revealed that Brine (B) used as a quenching medium for AA6101, has no significant effect on the hardness property of the AA6101 specimens, as it only increased the BHN from 39 to 40 $(0.39 \%)$

Table 5.: Result of AA6101 Hardness Test

\begin{tabular}{|c|c|c|c|c|c|}
\hline S/N & $\begin{array}{c}\text { Medium / } \\
\text { Temperature }\left({ }^{\circ} \mathrm{C}\right)\end{array}$ & BN1 & BN2 & BN3 & BHN \\
\hline
\end{tabular}

\begin{tabular}{|c|c|c|c|c|c|}
\hline 1. & $\begin{array}{l}\text { Water at } 250^{\circ} \mathrm{C} \\
\text { (W250) }\end{array}$ & 56.59 & 39.3 & 35.27 & 44 \\
\hline 2. & $\begin{array}{l}\text { Water at } 350^{\circ} \mathrm{C} \\
\text { (W350) }\end{array}$ & 28.87 & 28.87 & 28.87 & 29 \\
\hline 3. & $\begin{array}{l}\text { Water at } 450^{\circ} \mathrm{C} \\
\text { (W450) }\end{array}$ & 35.27 & 35.27 & 26.31 & 32 \\
\hline 4. & $\begin{array}{l}\text { Brine at } 250^{\circ} \mathrm{C} \\
\text { (B250) }\end{array}$ & 49.74 & 35.27 & 35.27 & 40 \\
\hline 5. & $\begin{array}{l}\text { Brine at } 350^{\circ} \mathrm{C} \\
\text { (B350) }\end{array}$ & 39.3 & 39.3 & 35.27 & 38 \\
\hline 6. & $\begin{array}{l}\text { Brine at } 450^{\circ} \mathrm{C} \\
\text { (B450) }\end{array}$ & 31.83 & 31.83 & 31.83 & 32 \\
\hline 7. & $\begin{array}{l}\text { Air at } 250^{\circ} \mathrm{C} \\
(\mathrm{A} 250)\end{array}$ & 64.96 & 56.59 & 56.59 & 59 \\
\hline 8. & $\begin{array}{l}\text { Air at } 350^{\circ} \mathrm{C} \\
\text { (A350) }\end{array}$ & 44.06 & 39.3 & 35.27 & 40 \\
\hline 9. & $\begin{array}{l}\text { Air at } 450^{\circ} \mathrm{C} \\
\text { (A450) }\end{array}$ & 28.87 & 35.27 & 35.27 & 33 \\
\hline 10. & $\begin{array}{l}\text { Furnace at } 250^{\circ} \mathrm{C} \\
\text { (F250) }\end{array}$ & 56.59 & 49.74 & 39.3 & 49 \\
\hline 11. & $\begin{array}{l}\text { Furnace at } 350^{\circ} \mathrm{C} \\
\text { (F350) }\end{array}$ & 31.83 & 28.87 & 35.27 & 32 \\
\hline 12. & $\begin{array}{l}\text { Furnace at } 450^{\circ} \mathrm{C} \\
\text { (F450) }\end{array}$ & 35.27 & 35.27 & 35.27 & 35 \\
\hline 13. & Control (C) & 39.3 & 39.3 & 39.3 & 39 \\
\hline
\end{tabular}

\subsection{Impact Test Results}

Table 6 shows the result of the Charpy Impact Test conducted on the heat-treated AA6101 specimens quenched in various media $(\mathrm{A}, \mathrm{B}, \mathrm{F}$, and $\mathrm{W})$ compared to that of the Control (C) sample. The Impact Absorbed Energy, Average Impact Absorbed Energy, and Impact Strength of the specimens was expressed respectively as: 


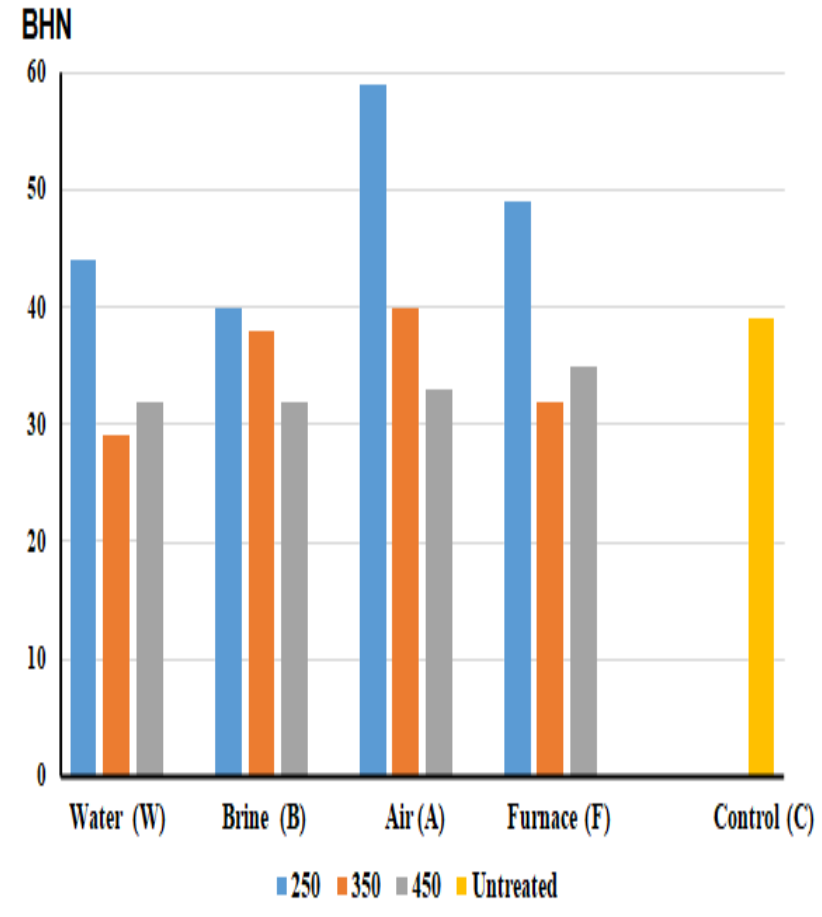

Fig 3.: Comparison of Hardness Properties of AA6101 Specimen Quenched in Different Media

IE (in Joules)

From equation (3), AvgIE $=\frac{E_{1}+E_{2}}{2}$ In Joules

From equation (4), $I S=\frac{A v g I E}{A}$ In Joules $/ \mathrm{m}^{3}$

Where $\mathrm{A}$ is the area of Impact specimen expressed as:

$\mathrm{A}=\mathrm{L} \times \mathrm{B} \times \mathrm{H}$

Figure 4 shows the comparison of Impact Absorbed Energy (IE) of AA6101 quenched in different media. It is seen from the graph that the Impact Absorbed Energy (IE) of the AA6101 samples increased drastically (in all quenching media) when the samples were heat-treated at $350^{\circ} \mathrm{C}$ but decreased a little when they were heated to $450^{\circ} \mathrm{C}$. Observations in this experiment have shown that $350^{\circ} \mathrm{C}$ is the most suitable temperature to enhance the Impact Absorbed Energy (IE). The increase for $350^{\circ} \mathrm{C}$ was (from $24 \%$ to $38 \%$ ) in all samples irrespective of quenching media. The graph also shows that there is no significant increase in the Impact Energy of the samples heat-treated at $250^{\circ} \mathrm{C}$ except for the ones cooled in the furnace (F250), and it had an increase of $13.7 \%$. The Impact of Absorbed Energy also increased by $17 \%$ in A450 and W450, and by $20 \%$ in F450

\subsection{Results of Microstructural Analysis}

The result of the metallographic analysis conducted on the AA6101 samples is shown in Figures 5 - 9.From Figures 6 to 9, it was noticed that there were no observable or significant changes from one sample or the others under the same conditions. It was noted that the

micrographs become becomes finer as the temperature increases from $250^{\circ} \mathrm{C}$ to $450^{\circ} \mathrm{C}$. The microstructures of those normalized in Air happened to be the finest of all micrographs. The next one that is finer to Air-cooled was the one quenched in water. The particles sizes were seen to be small as compared to those in from furnace cooled and quenched in brine solutions.

Table 6: Result of AA6101 Impact Test

\begin{tabular}{|c|c|c|c|c|c|}
\hline $\mathbf{S} / \mathbf{N}$ & $\begin{array}{c}\text { Medium / } \\
\text { Temperature } \\
\left({ }^{\circ} \mathbf{C}\right)\end{array}$ & $\mathrm{IE}_{1}$ & $\mathrm{IE}_{2}$ & $\begin{array}{c}\operatorname{Avg} I E \\
(J)\end{array}$ & $\begin{array}{c}\mathrm{IS} \\
\left(\mathrm{J} / \mathrm{m}^{2}\right)\end{array}$ \\
\hline 1 & $\begin{array}{c}\text { Water at } 250^{\circ} \mathrm{C} \\
(\mathrm{W} 250)\end{array}$ & 62 & 69 & 66 & 20 \\
\hline 2 & $\begin{array}{c}\text { Water at } 350^{\circ} \mathrm{C} \\
(\mathrm{W} 350)\end{array}$ & 80 & 84 & 82 & 24.84 \\
\hline 3 & $\begin{array}{c}\text { Water at } 450^{\circ} \mathrm{C} \\
(\mathrm{W} 450)\end{array}$ & 66 & 88 & 77 & 14 \\
\hline 4 & $\begin{array}{c}\text { Brine at } 250^{\circ} \mathrm{C} \\
\text { (B250) }\end{array}$ & 64 & 68 & 66 & 23.33 \\
\hline 5 & $\begin{array}{c}\text { Brine at } 350^{\circ} \mathrm{C} \\
\text { (B350) }\end{array}$ & 82 & 91 & 87 & 26.36 \\
\hline 6 & $\begin{array}{c}\text { Brine at } 450^{\circ} \mathrm{C} \\
\text { (B450) }\end{array}$ & 66 & 67 & 67 & 20.30 \\
\hline 7 & $\begin{array}{l}\text { Air at } 250^{\circ} \mathrm{C} \\
(\mathrm{A} 250)\end{array}$ & 61 & 68 & 65 & 19.67 \\
\hline 8 & $\begin{array}{l}\text { Air at } 350^{\circ} \mathrm{C} \\
(\mathrm{A} 350)\end{array}$ & 86 & 87 & 87 & 26.36 \\
\hline 9 & $\begin{array}{c}\text { Air at } 450^{\circ} \mathrm{C} \\
(\mathrm{A} 450)\end{array}$ & 70 & 83 & 77 & 23.33 \\
\hline 10 & $\begin{array}{c}\text { Furnace at } \\
250^{\circ} \mathrm{C}(\mathrm{F} 250)\end{array}$ & 70 & 80 & 75 & 22.72 \\
\hline 11 & $\begin{array}{c}\text { Furnace at } \\
350^{\circ} \mathrm{C}(\mathrm{F} 350)\end{array}$ & 90 & 92 & 91 & 27.58 \\
\hline 12 & $\begin{array}{c}\text { Furnace at } \\
450^{\circ} \mathrm{C}(\mathrm{F} 450)\end{array}$ & 74 & 84 & 79 & 29.94 \\
\hline 13 & Control (C) & 60 & 72 & 66 & 20 \\
\hline
\end{tabular}



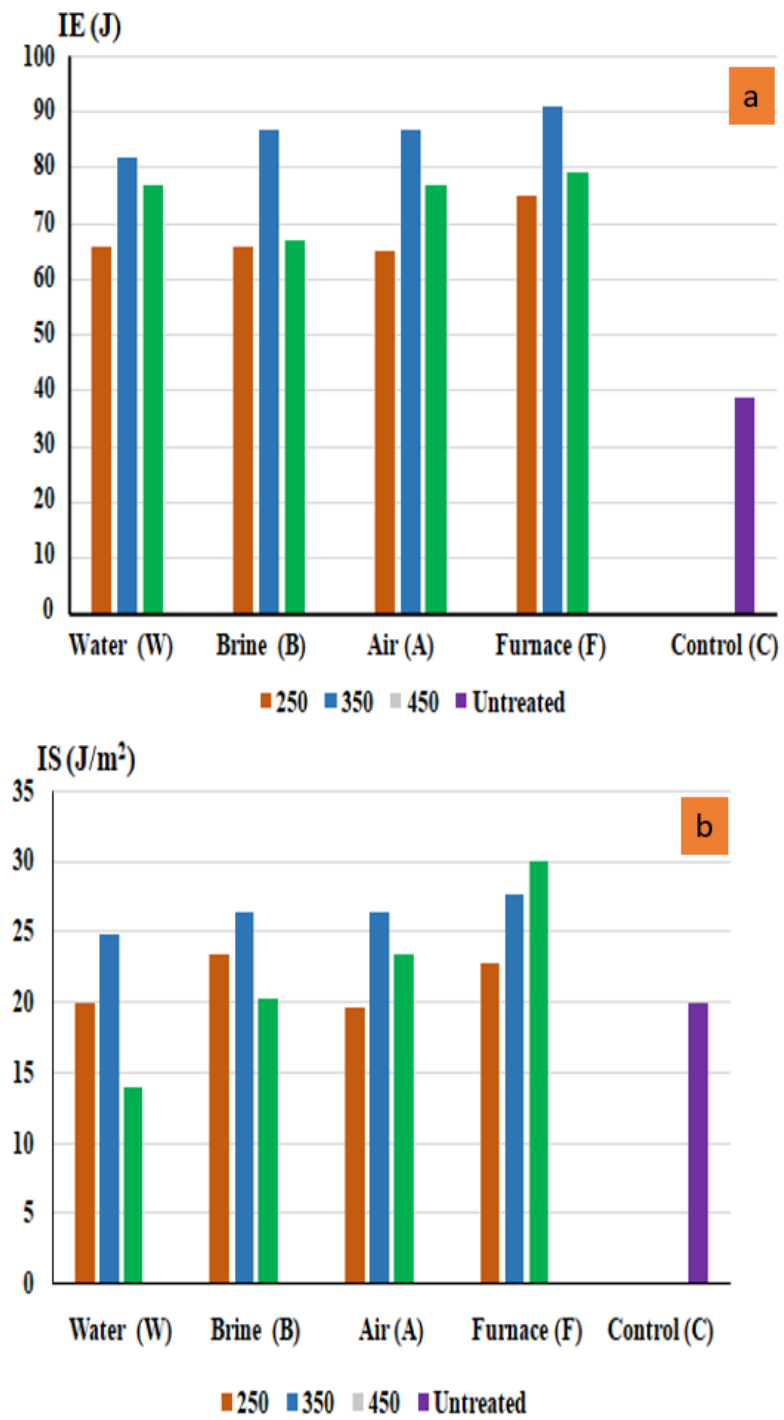

Figure 4: (a) Comparison of Impact Absorbed Energy (IE) (b) Impact Strength (IS) of AA6101 Quenched in Different Media

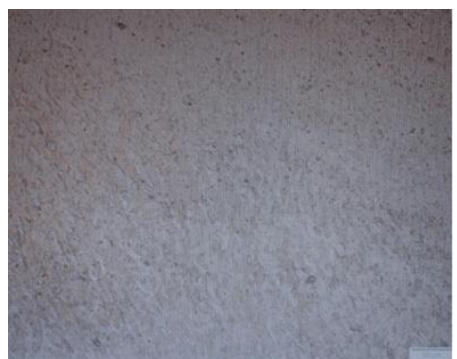

Fig 5: Micrograph of Control Sample (C) of AA6101 at 50 $\mu \mathrm{m}$

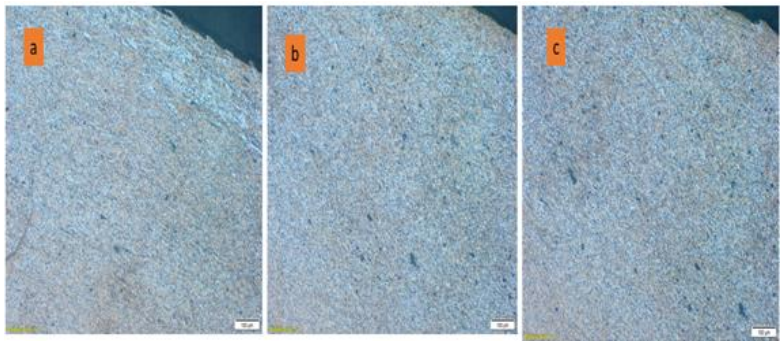

Fig 6: Micrograph of Heat Treated AA6101 Cooled in Air;

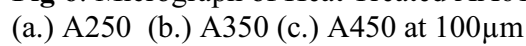

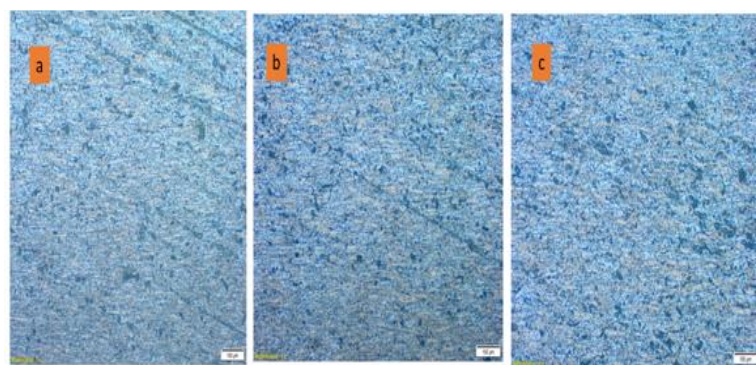

Fig 7: Micrograph of Heat Treated AA6101 Cooled in

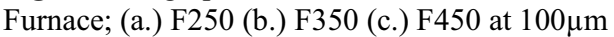
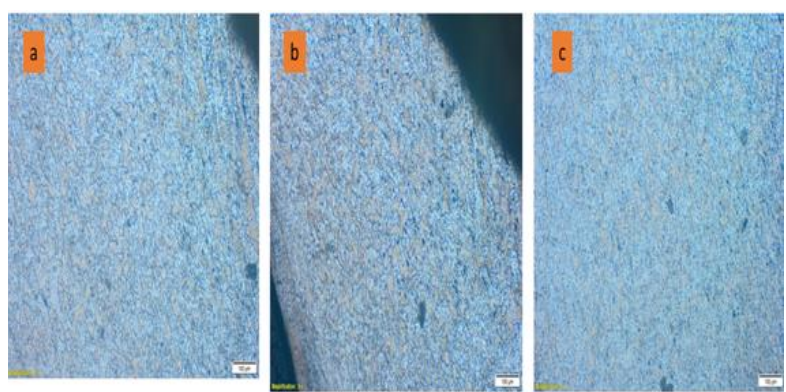

Fig 8.: Micrograph of Heat Treated AA6101 Quenched in

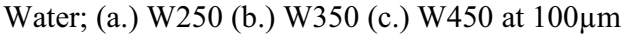
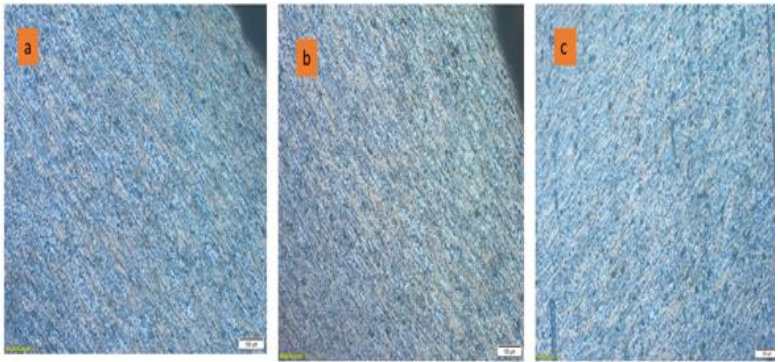

Fig 9. Micrograph of Heat Treated AA6101 Quenched in Brine; (a.) B250 (b.) B350 (c.) B450 at $100 \mu \mathrm{m}$

\section{Conclusion}

This research found that $250^{\circ} \mathrm{C}$ is the best temperature for increasing the hardness property of AA6101 and that air is the best cooling medium, followed by cooling in the furnace. It has also been established that Brine Solution used as a quenching medium has no significant effect on the hardness property of AA6101. Also, it was discovered that, regardless of the quenching medium, $350^{\circ} \mathrm{C}$ is the best temperature for increasing the Impact Absorbed Energy (IE) and Impact Strength (IS) of AA6101. Cooling AA6101 in a furnace at $350^{\circ} \mathrm{C}$ increases the IE and IS by $38 \%$, while using Brine or Air increases the IE and IS by $32 \%$.

\section{References}

1. Mulaba-Kapinga D, Nyembwe KD, Ikumapayi OM, Akinlabi ET. Manufacturing Review. 7, 25 (2020). 
2. Akinlabi ET, Ikumapayi OM, Bodunde OP, Adaramola BA, Uchegbu ID, Fatoba SO. Int. J. Emerging Technol. 11(5), 290-7 (2020).

3. Mukhopadhyay P. Alloy designation, processing, and use of AA6XXX series aluminium alloys. International Scholarly Research Notices. 2012.

4. Medvedev A, Murashkin MY, Kazykhanov V, Valiev RZ, Medvedev AE, Hodgson PD, Lapovok R. Advanced Engineering Materials. 20(11)1800695 (2018).

5. Ikumapayi OM, Akinlabi ET, Fatoba SO, Kazeem RA, Afolabi SO, Adeoye AO, Akinlabi SA. Advances in Material Science and Engineering. 150-168 (2021)

6. Tamasgavabari R, Ebrahimi AR, Abbasi SM, Yazdipour AR. Materials Science and Engineering:

A. 736, 248-57 (2018).

7. Afolalu SA, Ikumapayi OM, Ogedengbe TS, Emetere ME. Revue des Composites et des Matériaux Avancés 31(3). (2021).

8. Ikumapayi OM, Akinlabi ET, Majumdar JD, Surface Topography: Metrology and Properties. 7(3), 035013 (2019)

9. Vuherer T, Maruščak PO, Samardžić I. Metalurgija.51(3), 301 (2012).

10. Ikumapayi OM, Akinlabi ET, Majumdar JD. Int. J. Mech. Eng. Technol. 9(8), 534 (2018).

11. ASTM E407-07. Standard practice for microetching metals and alloys. ASTM International. 2015.

12. Atlas Steel, (2019),"Aluminium Alloy Data Sheet 6101," https://www.onlinemetals.com/en/productguide/alloy/6101

13. ASTM, "E112-12, Standard Test Methods for Determining Average Grain Size, ASTM International, West Conshohocken, PA, 2012, www.astm.org,"

14. ASM Aerospace Specification Metals Inc. 1978. Available from: http://asm.matweb.com/search/SpecificMaterial.asp ?bassnum=MA6063T4 [Accessed 21 August 2018 